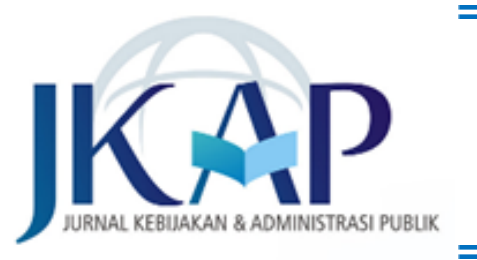

JKAP (Jurnal Kebijakan dan Administrasi Publik) Vol.21 (1), May 2017, 76-98

ISSN 0852-9213 (Print), ISSN 2477-4693 (Online)

Available Online at https://journal.ugm.ac.id/jkap

\title{
Evaluation of the Implementation of Tourism Policy
}

\author{
Yerik Afrianto Singgalen \\ Politeknik Perdamaian Halmahera \\ singgalen@yerik.gmail.com \\ Pamerdi Giri Wiloso \\ Universitas Kristen Satya Wacana \\ pamerdi.giri@staff.uksw.edu \\ Gatot Sasongko \\ Universitas Kristen Satya Wacana \\ gatot.sasongko@staff.uksw.edu
}

\begin{abstract}
This purpose of the study is to evaluate the implementation of tourism programs in Bobale Island, Kakara Island, Tagalaya Island and Meti Island in North Halmahera District. The study is based on a model developed by George Edward III, and used qualitative methods to collect and analyze data. Data collection techniques used included in-depth interviews, observation and study of the documents. Results of the study showed that resources, communication, disposition and bureaucratic structure are the main factors that influence the implementation of tourism policies are. Nonetheless, this study also showed that public support through public participation in the implementation process is also an important factor that determines the success of tourism policy. To that end, community support or community participation should be an important factor that must be taken into account in the formulation of development priorities of Tourism development Master plan for North Halmahera District government.
\end{abstract}

Keywords: bureaucratic system, communication, community participation, disposition, policy implementation, resources 


\section{INTRODUCTION}

Research on tourism policy begun in 1990s. This is evidenced by a 1996 research by Kadar on the implementation of tourism development policy in Aceh province. By the same token, Habbibuw (1997) conducted research on the implementation of tourism development policy in Mojokerto district. Toward the late 1990s, 1999 to be exact, Pakpahan conducted a study on the implementation of tourism institutional development policy on the tourism office of Yogyakarta city government. Some of the key issue that were the focus of the previous studies on tourism development policies in various areas included funding sources and resources, communication, disposition of program implementers in influencing the performance of the program. Results underscored the importance of the four factors in the success or lack of it, of tourism development programs.

Research on tourism policy during 2000 s continued to focus on the same factors that were also central for research in 1990s. This is reflected in the focus of the research that continued to be the influence of funding and other resources, communication, disposition of policy implementers and the bureaucracy on the performance of tourism development programs. A study by Huttapea (2001) on the implementation of tourism activities in Jayapura city is a good example of such research. Besides, other researchers embarked on research that evaluated the performance of tourism planning based on an input-output model. Such a research was conducted by Basri (2002). Basri's study investigated the performance of the implementation of RIPPDA, West Kalimantan province, while another study by Dewi (2005) on the effectiveness of implementing tourism development policy in Palembang was another one.

As regards tourism policy, some researchers investigated tourism policy outcomes and benefits. A study by Rettob (2008) on the implementation of RIPPDA in Papua province, another one by Agistiani (2014) on the implementation of poverty reduction policy in Brayut tourism village. $\mathrm{Ob}-$ servation of previous research on tourism policy leads to the conclusion that economic aspect of the sector has attracted the most research attention. Some researchers who have conducted studies on the economic development of tourism include (Brida \& Risso, 2010; Hall, 2009; Haydock, 2014; Yang $\&$ Chen, 2009), while other researchers carried out studies on the relationship between tourism economic development and tourism products and services, in this case tourist attractions (Getz \& Page, 2005; O'Sullivana, Pickernella, \& Senyardb, 2009; Preuss, 2009; Robertson, Rogers, \& Leask, 2009). Nonetheless, not all previous research on tourism policy focused on tourism economic policy. Some researchers investigated the policy that regulates the collaboration among stakeholders in tourism sector (Theodoraki, 2009; Wesley \& Pforr, 2010; Yaghmour \& Scott, 2009). This is an indication that the focus of research on tourism economic policy is increasingly being tailored toward the economic aspects.

In addition to economic aspects, some research on tourism policy investigates social aspects. Some of the researchers who have focused on social aspects of tourism policy such as (Curry \& Brown, 2010; Doherty, 2009; Nunkoo \& Ramkissoon, 2010; Roberts, 2010; Saayman, Van der Merwe, Saayman, \& Mouton, 2009). In fact some researchers investigated the sustainability of tourism development (Dredge \& Whitford, 2011; Hall, 2011) , and others have looked into community based tourism (Wray, 2011). To that end, it is apparent that developments in research on tourism policy have delved into economic, and social aspects of society who live in the vicinity of tourist attractions.

In a study on tourism policy, Veriani (2009) used Edward III model to identify factors that influence successful implementation. Veriani (2009) found that determinants of successful implementation of tourism policy include, resources, attitude and disposition of implementers of the policy and the bureaucratic system that implements the policy. In the same vein, a research by Fianda (2008) found that resources, communication, attitude and disposition of implementers of the policy and bureaucracy system are key determinants of success of policy performance. Based on the foregoing, it is 
apparent that research results showed that financial resources, and other resources as well as human resources influence the implementation of the policy. In addition, attitude and disposition of implementers of activities are also key factors that influence the performance of the tourism policy.

Issues that most previous research on the implementation of tourism development policy, have largely focused on aspects of the government bureaucracy (resources, communication, disposition of implementers of the policy and the bureaucracy system). In light of that, the objective of this research is to evaluate the implementation of tourism policy in Bobale, Meti, Tagalaya and Kakara islands inn North Halmahera district. The research not only evaluates aspects that relate to the bureaucracy as listed above, but also for get a more comprehensive and complete picture of the determinants of the policy, assesses the impact that community support as gauged from public participation, on the development of tourism in the district.

\section{RESEARCH METHODS}

This research used descriptive methods that is underpinned by a case study approach based on Edward III analysis model. The research assessed resources, communication, attitude and disposition of implementers of tourism policy and the bureaucracy system that is responsible for implementing the policy.

The researchers base their arguments on Creswell (2009) who posits that qualitative research starts with assumptions that form and influence study of the problem that is researched which is also relates to the meaning individuals or group of individuals attach to the problem. To study the problem, qualitative researchers use the latest qualitative approach in conducting the research, collecting data using techniques that take into account sensitivity of the society toward the issue that is researched, conduct analysis of inductive and deductive data, and identify various patterns and themes that emerge. A report of the findings must encompass various voices of participants, reflections of the researchers, descriptions and interpretation of the problem that is investigated and iden- tify and describe the contribution the research makes to literature and make recommendations for change.

This research started with a results of the documentary study that showed that the implementation of tourism development program in North Halmahera was not entirely satisfactory, hence performance was far from expectations as indicated in the district tourism development Master plan (RIPPDA) for North Halmahera, 20112015. During the research process, the researchers conducted observations of several tourist attractions that are placed on the priority list in the development of infrastructure and facilities to support tourist objects in Kakara, Meti, Tagalaya and Bobale islands. Results of the observations showed that infrastructure and facilities to support tourism in in some tourist attractions has not been built as yet. The implication that the implementation of tourism development policy on the ground is not in line with district government expectations and goals that are stated in RIPPDA. What is more disconcerting though, is that even where infrastructure and facilities has been development, maintenance has not been done which has led to damage and dereliction.

In an endeavor to identify problems that have hampered the implementation of tourism development program in the district, the research team conducted an in-depth interview of members of the public who live in the vicinity of tourist attractions, village heads and district tourism and culture office head, North Halmahera district (Theo Sosebeko, in 2015 and Joice Betsy Mahura, in 2016). Outcome of the interview of the informants were transcribed and subsequently clarified in line with themes that formed a matrix. Researchers used triangulation technique to synchronize results of filed observation, in-depth interview and study of documents. The documents that were assessed include district Master plan for the development of tourism in North (RIPPDA), 20052010, Master plan for the development of tourist attractions (RIPPOW) 2006-2010, and district Master plan for the development of tourism in North (RIPPDA), 2011-2015. To sharpen the analysis, the research team studied and analyzed developments in 
RIPPDA during 2005-2016 fiscal years

\section{RESULTS AND DISCUSSION}

Presentation of results of this research start with giving a general picture of the formulation of the Master plan on tourism development and Master plan on the development of tourist attractions in the district. Components of development, analysis of internal and external of tourism environment in North Halmahera, development strategy, evaluation, and categorization, and indicators of the development programs.

Subsequently, discussion of the evaluation of development strategies, evaluation of results of the implementation strategy, in turn for Bobale, Meti, Tagalaya and Kakara islands. Then after the research team discusses research findings and relates them to existing literature, to identify the key problems that emerge in the implementation of the Master plan for tourism development in North Halmahera district.

\section{Master plan for the development of tour- ism (RIPPDA) in North Halmahera dis- trict (RIPPDA), 2010-2015}

The formulation of RIPPDA for North Halmahera district was based on four issues , interalia; formidable challenges facing the development of local, national and international tourism; the strong desire of all stakeholders in the tourism sector to enhance the competiveness of the sector; efforts by local government (Pemda) to orientate the tourism sector as an alternative source of local government revenue (PAD); conduct adjustment of policy direction, strategy and inter sectoral programs to ensure that there is long term consistence between National Master plan for tourism development and North Halmahera Master plan for the development of tourism .

RIPPDA is part of the local government development plan, which is derived from macro development plan, as a specific (operational) development plan as well as reference in the management and development of tourism, for 5-10 years in future. With respect to the context of formulation of RIPPDA for North Halmahera district, legal framework include: Law No 10/. 2009 on tourism; Law No 32 / 2009 on the protection and management of the environment ; Law No 32 / 2004 on balancing of local government and central government financing; Lawq No 26 / 2007 on spatial management; Law No 27 / 2007 on the management of remote coastal areas; Government regulation No 50 / 2011 on the National Master plan for tourism development (RIPPARNAS); Presidential instruction No $16 / 2009$ on the development of creative economy; North Maluku province Master plan for the development of tourism (RIPPARDA) , 2010; spatial plan for North Halmahera (RTRW) ; strategic plans for district government offices (RENSTRA)SKPD for the tourism and culture office, North Halmahera district ,2011-2016; RIPPDA North Halmahera for 2008.

The goals of North Halmahera Master plan for the development of tourism, include : formulate the direction of development and concept, policy and strategic plan that will form the foundation for the development of tourist attractions in North Halmahera district plan; prepare the direction, strategy, and pattern of combining the development of tourist attractions in North Halmahera district.

Figure 1 shows that the formulation of RIPPARDA North Halmahera is on the basis of RIPPARNAS and RIPPARDA for North Maluku province, both of which are adjusted in line with government regulation No $50 /$ 2011 and gubernatorial instruction (SK). Subsequently, RIPPARDA for North Halmahera district is synchronized with district government regulations as embodied in the Master plan for the development of tourism areas (RIPKW), followed by the translation of each RIPKW into an Master action plan for the development of tourist attractions (RIPPOW). Subsequently, RIPPDA formulation process is subjected to a feasibility study, and broken down into a detailed engineering design through the district head instruction, and the head of tourism and culture office instruction.

Outputs of RIPPDA for North Halmahera include : a profile of data of tourism in North Halmahera district which describe the potential of tourism in the district; results of analysis of the condition of tourism in North 


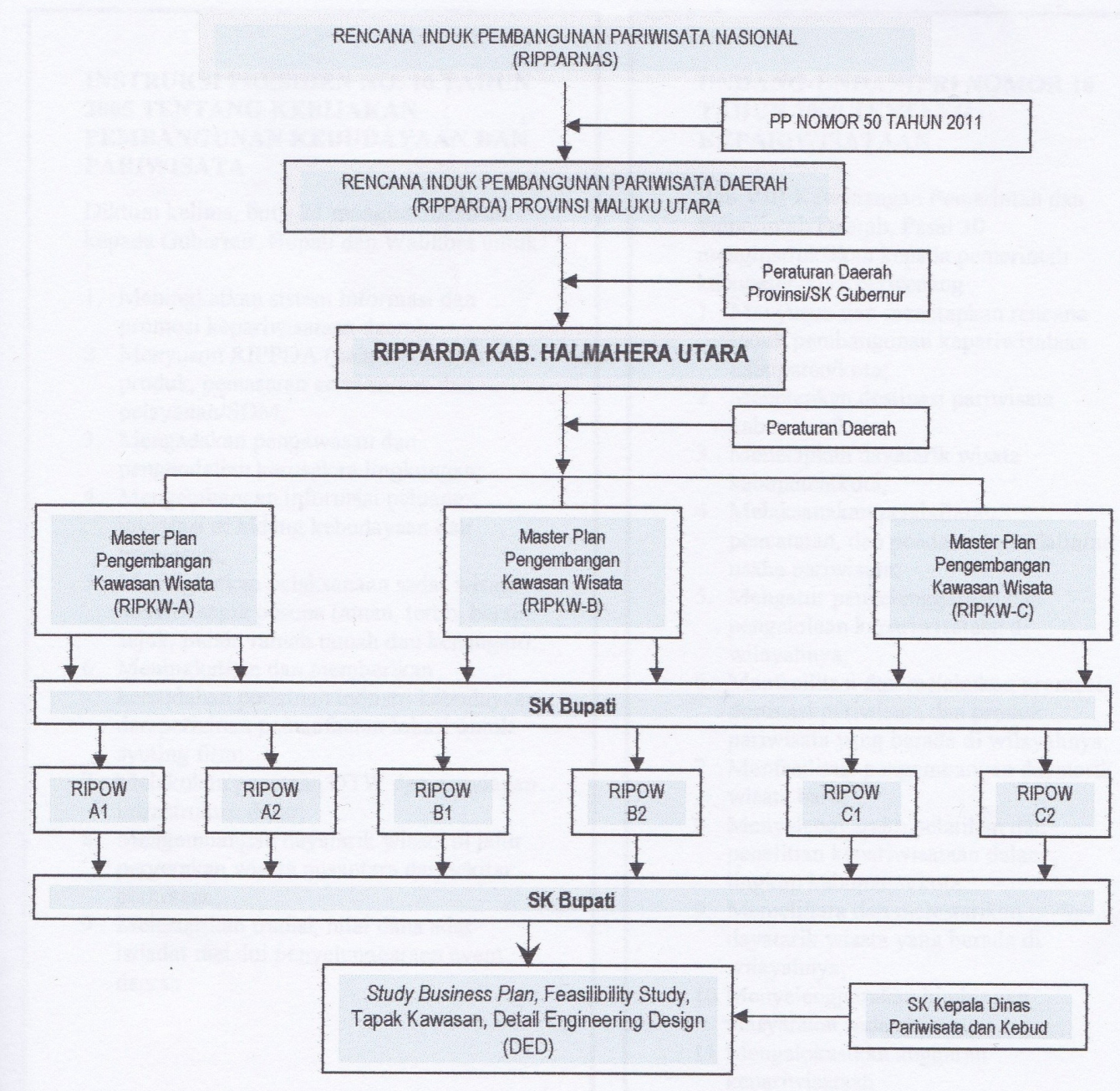

Figure 1. Hierarchy in Tourism Planning right from the national level to DTW Source: RIPPARDA HALUT 2011

Halmahera district that include a description and analysis of the condition and developments of tourism aspects; formulation of vision and mission, goals and development targets for tourism in North Halmahera district; formulation of strategy, plan, and Indicative programs for the development of tourism in North Halmahera district.

Figure 2 shows that the formulation of RIPPDA in North Halmahera district is based on outcomes of primary data that is collected using observation and FGD (Focus Group Discussion) as well as secondary data, which is a compilation and interpretation of initial data. Subsequently, results of the processing of primary data and secondary data area analyzed using SWOT (Strengths, Weaknesses, Opportunities, and Threats) technique. The potential and problems that affect tourism sector identified and used to determine the potential products and services and the market for tourists. Results obtained in the previous step are used to formulate the vision, and mission for the development of tourism in North Halmahera district which form the basis for the formation of policy, strategy, plan and recommendations of intersectoral programs.

\section{Components of Tourism development}

Components of tourism development are divided into four parts: tourism industry, tourist destinations; tourism marketing and institutions. The development of indicative tourism programs in North Halmahera district are based on the following components.

The tourism industry component covers: structure development (functions, hierarchy, relations) tourism industry; competitiveness of tourism products; partnership 
Table 1. Internal and External conditions of Tourism sector in North Halmahera Source: RIPPARDA HALUT 2011

\begin{tabular}{ll}
\hline \multicolumn{1}{c}{ External condition } & \multicolumn{1}{c}{ Internal condition } \\
\hline Globalization & $\begin{array}{l}\text { Limited access of tourists and mode of trans- } \\
\text { portation across islands }\end{array}$ \\
$\begin{array}{l}\text { Global marketing } \\
\text { Millennium development goals } \\
\begin{array}{l}\text { Tendencies and Developments in Global infrastructure and general facilities } \\
\text { tourism }\end{array}\end{array}$ & $\begin{array}{l}\text { Limited tourist facilities } \\
\text { Limited or scarcity of professional Human } \\
\text { resources to manage tourists in the area }\end{array}$ \\
Code of Ethics in Global Tourism & $\begin{array}{l}\text { Suboptimal management of tourist attractions } \\
\text { and low creativity of the local population }\end{array}$ \\
$\begin{array}{l}\text { Developments in Asia and Pacific and } \\
\text { ASEAN region }\end{array}$ & $\begin{array}{l}\text { Minimal involvement of the local community } \\
\text { due to misunderstanding of the benefits that } \\
\text { tourism development contributes to the area }\end{array}$ \\
$\begin{array}{l}\text { The revitalization of creative economy as the } \\
\text { fourth Economic wave }\end{array}$ & $\begin{array}{l}\text { Shortage of investment in the tourism sector } \\
\text { The shift in national development policy }\end{array}$ \\
$\begin{array}{l}\text { Leople or community empowerment based } \\
\text { the development of tourism }\end{array}$ \\
$\begin{array}{l}\text { Realization of the tourism awareness concept } \\
\text { in tourist destination areas is still poor }\end{array}$ \\
$\begin{array}{l}\text { Ineffective coordination and synergy across } \\
\text { sectors and regions } \\
\text { Partnership between the government and the } \\
\text { private sector is still weak hence suboptimum } \\
\text { Promotion and marketing of tourism is still } \\
\text { insufficient }\end{array}$ \\
\hline
\end{tabular}

with tourism enterprises; business credibility; accountability for natural environment and social culture. The tourism destination component entails: development of tourist attractions; developing infrastructure; developing general facilities; developing tourism facilities and providing integrated and sustainable community empowerment.

Meanwhile, the marketing component includes: joint tourism marketing, integrated and sustainable with the involvement of all stakeholders; responsible marketing that also attempts to enhance Indonesian image as a competitive tourist destination. The tourism institution component includes: the development of local government organizations; private sector, and the local community; human resource development; regulations and operational mechanisms in the tourism sector.

\section{Analysis of external and internal condi- tions of tourism in North Halmahera dis- trict}

Tourism planning in North Halmahera district identifies factors that influence tourism supply and tourism demand, which are crucial to achieve development goals. To that end, conducting external analysis helps in identifying problems in the tourism sector in North Halmahera as a pathway for strengthening the ability of the district to face globalization and other dynamics that bear on district economic development. Outcome of the SWOT exercise on the tourism sector in North Halmahera as gleaned from RIPPDA are described in table 1.

The internal conditions of tourism in North Halmahera still lag current developments in globalization, global warming, eco- 
Table 2. Weights for each parameter used in evaluating DTW

\begin{tabular}{lll}
\hline No & Parameter & Weight \\
\hline 1 & $\begin{array}{l}\text { Quality and uniqueness } \\
\text { of the tourist attraction }\end{array}$ & 0.25 \\
2 & $\begin{array}{l}\text { Scale of marketing } \\
\text { reach }\end{array}$ & 0.20 \\
3 & Number of tourist visits & 0.20 \\
4 & Accessibility & 0.15 \\
5 & Supporting infrastruc- & 0.10 \\
& ture and facilities & \\
6 & Other factors & 0.10 \\
Total & & 1.00 \\
\hline
\end{tabular}

nomic policy changes, and developments in development concepts. To that end, there is need for the formulation in both policy direction and development in such a manner that can enhance the development of tourism in North Halmahera in line with components of tourism development interalia, tourism industry, tourism destination, tourism marketing, and tourism institutions.

Based on RIPPDA HALUT 2011, the tourism industry in North Halmahera district is yet to attain its maximum potential largely due to limited investment in tourism, ineffective coordination across relevant sectors and between the government and partners in the private sectors. In is thus apparent that conditions in tourist destinations face limited accessibility, mode of transportation, general facilities and infrastructure, tourist facilities, and absence of competent and effective tourism management of tourist attractions. On the other hand, with regards to tourism marketing conditions in North Halmahera, indications point to absence of effective promotion and marketing activities of tourism in the area. Meanwhile, as regards tourism institutions in North Halmahera, it is apparent that conditions on the ground reflect insufficient involvement of the local community in the development of tourism, shortages in human resources with expertise in tourism, and failure to implement fully the concepts of tourism awareness and sapta pesona. Based on the foregoing, therefore, there is need to formulate tourism development program in such a way that it can propel the sector to become one of those that have high competitiveness in North Halmahera dis- trict.

Strategy for developing tourism, Evaluation, and Categorization, and Indicative programs in Bobale, Meti and Kakara islands.

The determination of the development strategy to enhance the attraction of tourists to North Halmahera district, starts with the evaluation of the quality and uniqueness of tourist attractions, diversity of attractions, environmental conditions, scale of marketing of tourist attractions, number of tourist visits to the attraction, supporting accessibility and reach, the condition of roads, ease of reach to those destinations, supporting infrastructure and general facilities, supporting equipment, capacity and other factors.

Table 2 shows the process of quantifying the potential for tourist attraction area (DTW) which is effected by giving score or weight for each parameter. Each parameter is given a special coefficient value in accordance with level of importance/potential in supporting tourism.

Table 3 shows the criteria used in evaluating the attractiveness of tourism in North Halmahera with the purpose of identifying tourist objects that have high competitiveness (classification A), outstanding (Classification B) and potential (classification C). Based on RIPPDA HALUT 2011 data, the research team was able to identify 13 tourist area (DTW) with classification A, 8 DTW with outstanding competitiveness classification $\mathrm{B}$ and 35 DTW with potential classification $\mathrm{C}$. Thus, there 
Table 3. Evaluation criteria used to evaluate the potential of tourism area in North Halmahera Source: RIPPARDA HALUT 2011

\begin{tabular}{|c|c|c|c|c|c|c|}
\hline \multirow{2}{*}{ Parameter } & \multirow{2}{*}{$\begin{array}{l}\text { Details of } \\
\text { evaluation } \\
\text { elements }\end{array}$} & \multicolumn{5}{|c|}{ Evaluation } \\
\hline & & Value 1 & Value 2 & Value 3 & Value 4 & Value 5 \\
\hline $\begin{array}{l}\text { Quality and } \\
\text { Uniqueness } \\
\text { of a DTW }\end{array}$ & $\begin{array}{l}\text { Uniqueness } \\
\text { is evaluated } \\
\text { on the basis } \\
\text { of the value } \\
\text { of tourist } \\
\text { attraction of } \\
\text { an area } \\
\text { which can- } \\
\text { not be found } \\
\text { or not in } \\
\text { another area. } \\
\text { The unique- } \\
\text { ness of an } \\
\text { area com- } \\
\text { prises simi- } \\
\text { larity of } \\
\text { type, quality, } \\
\text { condition, } \\
\text { and impres- } \\
\text { sion that the } \\
\text { area imparts } \\
\text { on viewers } \\
\text { or those who } \\
\text { pay visits to } \\
\text { it. }\end{array}$ & $\begin{array}{l}\text { If many DTW are } \\
\text { identified in anoth- } \\
\text { er area ,then area } \\
\text { does not have any } \\
\text { uniqueness }\end{array}$ & $\begin{array}{l}\text { If there are } \\
\text { few DTW } \\
\text { with the } \\
\text { same fea- } \\
\text { tures in other } \\
\text { area (in one } \\
\text { district) but } \\
\text { there are } \\
\text { specific } \\
\text { uniqueness } \\
\text { in each }\end{array}$ & $\begin{array}{l}\text { If such DTW } \\
\text { are rare and } \\
\text { not easy to } \\
\text { find in other } \\
\text { areas (in one } \\
\text { province) but } \\
\text { have specific } \\
\text { uniqueness }\end{array}$ & $\begin{array}{l}\text { If DTW } \\
\text { with such } \\
\text { features are } \\
\text { rare in oth- } \\
\text { er areas (in } \\
\text { one coun- } \\
\text { try) and } \\
\text { have spe- } \\
\text { cific } \\
\text { uniqueness }\end{array}$ & $\begin{array}{l}\text { If DTW can- } \\
\text { not be found } \\
\text { in any other } \\
\text { location or } \\
\text { place (in the } \\
\text { World( hence } \\
\text { has high } \\
\text { uniqueness }\end{array}$ \\
\hline
\end{tabular}

\begin{tabular}{|c|c|c|c|c|c|c|}
\hline $\begin{array}{l}\text { Similarity of } \\
\text { the attraction }\end{array}$ & $\begin{array}{l}\text { Similarity of } \\
\text { attraction } \\
\text { (Quantity) is } \\
\text { evaluated } \\
\text { based on the } \\
\text { size or level } \\
\text { of attraction } \\
\text { the object } \\
\text { has }\end{array}$ & $\begin{array}{l}\text { If DTW has one } \\
\text { source of attraction }\end{array}$ & $\begin{array}{l}\text { If DTW the } \\
\text { object has } \\
\text { two sources } \\
\text { of attraction }\end{array}$ & $\begin{array}{l}\text { If DTW the } \\
\text { object has } \\
\text { three sources } \\
\text { of attractions }\end{array}$ & $\begin{array}{l}\text { If DTW } \\
\text { the object } \\
\text { has four } \\
\text { sources of } \\
\text { attractions }\end{array}$ & $\begin{array}{l}\text { If DTW the } \\
\text { object has } \\
\text { five or more } \\
\text { sources of } \\
\text { attractions }\end{array}$ \\
\hline
\end{tabular}


Yerik Afrianto Singgalen, Pamerdi Giri Wiloso and Gatot Sasongko-Evaluation of the Implementation....

\begin{tabular}{|c|c|c|c|c|c|c|}
\hline $\begin{array}{l}\text { Condition of } \\
\text { the Environ- } \\
\text { ment }\end{array}$ & $\begin{array}{l}\text { Condition of } \\
\text { the environ- } \\
\text { ment is evalu- } \\
\text { ated on the } \\
\text { basis of the } \\
\text { condition of } \\
\text { the physical/ } \\
\text { spatial envi- } \\
\text { ronment and } \\
\text { attractiveness } \\
\text { of tourist } \\
\text { objects and } \\
\text { the availabil- } \\
\text { ity of land for } \\
\text { the develop- }\end{array}$ & $\begin{array}{l}\text { If tourist attraction } \\
\text { does not have spatial } \\
\text { planning/ } \\
\text { management, and } \\
\text { there is no land to } \\
\text { support the develop- } \\
\text { ment of the object }\end{array}$ & $\begin{array}{l}\text { If the tourist } \\
\text { attraction does } \\
\text { not have spa- } \\
\text { tial planning } \\
\text { and manage- } \\
\text { ment, but land } \\
\text { is available e } \\
\text { to support its } \\
\text { development }\end{array}$ & $\begin{array}{l}\text { If the tourist } \\
\text { attraction has } \\
\text { spatial manage- } \\
\text { ment but there } \\
\text { are problems in } \\
\text { managing tour- } \\
\text { ists /visitors } \\
\text { and conflicts }\end{array}$ & $\begin{array}{l}\text { If the tourist } \\
\text { attraction has } \\
\text { spatial man- } \\
\text { agement and } \\
\text { does not } \\
\text { have prob- } \\
\text { lems in man- } \\
\text { aging tourists } \\
\text { and visitors. }\end{array}$ & $\begin{array}{l}\text { If the tourist } \\
\text { attraction has } \\
\text { spatial man- } \\
\text { agement and } \\
\text { does not any } \\
\text { problems in } \\
\text { managing } \\
\text { tourists / } \\
\text { visitors and } \\
\text { there is land } \\
\text { available for } \\
\text { the develop- } \\
\text { ment of the } \\
\text { tourist attrac- } \\
\text { tions. }\end{array}$ \\
\hline
\end{tabular}

ment of tour-

ist objects

\begin{tabular}{|c|c|c|c|c|c|c|}
\hline $\begin{array}{l}\text { Scale of mar- } \\
\text { keting of the } \\
\text { tourist attrac- } \\
\text { tions }\end{array}$ & $\begin{array}{l}\text { The reach of } \\
\text { the tourist } \\
\text { object } \\
\text { ( whether the } \\
\text { tourist object } \\
\text { draws local, } \\
\text { national and } \\
\text { international } \\
\text { tourists) }\end{array}$ & $\begin{array}{l}\text { If the reach of the } \\
\text { object is limited to } \\
\text { local tourists (district } \\
\text { and surrounding } \\
\text { areas }\end{array}$ & $\begin{array}{l}\text { If the reach of } \\
\text { the object goes } \\
\text { as far as at- } \\
\text { tracting tour- } \\
\text { ists at the } \\
\text { district and } \\
\text { beyond (one } \\
\text { province) }\end{array}$ & $\begin{array}{l}\text { If the reach of } \\
\text { the object goes } \\
\text { as far one prov- } \\
\text { ince and be- } \\
\text { yond }\end{array}$ & $\begin{array}{l}\text { If the reach } \\
\text { of the object } \\
\text { goes as far as } \\
\text { attracting } \\
\text { tourists at the } \\
\text { national level }\end{array}$ & $\begin{array}{l}\text { If the reach of } \\
\text { the object goes } \\
\text { as far as at- } \\
\text { tracting tour- } \\
\text { ists at the } \\
\text { international } \\
\text { level }\end{array}$ \\
\hline $\begin{array}{l}\text { Number/level } \\
\text { of tourist } \\
\text { visits to the } \\
\text { object }\end{array}$ & $\begin{array}{l}\text { Number of } \\
\text { tourists who } \\
\text { visit the object } \\
\text { and attractive- } \\
\text { ness of the } \\
\text { area }\end{array}$ & $\begin{array}{l}\text { If the number of } \\
\text { tourists is less than } \\
20,000 \text { per year }\end{array}$ & $\begin{array}{l}\text { If the number } \\
\text { of tourists to } \\
\text { the object } \\
\text { falls in the } \\
20.001-50.000 \\
\text { range per year }\end{array}$ & $\begin{array}{l}\text { If the number } \\
\text { of tourists falls } \\
\text { in the } 50.001- \\
100.000 \text { range } \\
\text { per year }\end{array}$ & $\begin{array}{l}\text { If the number } \\
\text { of tourists } \\
\text { falls in the } \\
100.001- \\
500.000 \\
\text { range per } \\
\text { year }\end{array}$ & $\begin{array}{l}\text { If the number } \\
\text { of tourists falls } \\
\text { in } 500.001- \\
1.000 .000 \text { per } \\
\text { year }\end{array}$ \\
\hline $\begin{array}{l}\text { Accessibility } \\
\text { and reach }\end{array}$ & $\begin{array}{l}\text { Availability of } \\
\text { mode of trans- } \\
\text { portation to } \\
\text { the tourists } \\
\text { attraction and } \\
\text { attractiveness } \\
\text { of the are }\end{array}$ & $\begin{array}{l}\text { If there is no mode of } \\
\text { transportation availa- } \\
\text { ble }\end{array}$ & $\begin{array}{l}\text { If the modes } \\
\text { of transporta- } \\
\text { tion is very } \\
\text { limited/seldom }\end{array}$ & $\begin{array}{l}\text { If there are } \\
\text { various modes } \\
\text { of transporta- } \\
\text { tion available } \\
\text { and in good } \\
\text { condition }\end{array}$ & $\begin{array}{l}\text { If there are } \\
\text { various } \\
\text { modes of } \\
\text { transporta- } \\
\text { tion availa- } \\
\text { ble and in } \\
\text { normal } \\
\text { condition }\end{array}$ & $\begin{array}{l}\text { If there are } \\
\text { various modes } \\
\text { of transporta- } \\
\text { tion available } \\
\text { and are in } \\
\text { sufficiently } \\
\text { good condi- } \\
\text { tion }\end{array}$ \\
\hline Road quality & $\begin{array}{l}\text { Quality of } \\
\text { roads toward } \\
\text { the tourist } \\
\text { attraction }\end{array}$ & $\begin{array}{l}\text { If most tourist objects } \\
\text { are only accessible } \\
\text { by paths and village } \\
\text { roads }\end{array}$ & $\begin{array}{l}\text { If most tour- } \\
\text { ists objects are } \\
\text { accessible by } \\
\text { sub district } \\
\text { roads/sea } \\
\text { lanes }\end{array}$ & $\begin{array}{l}\text { If most tourists } \\
\text { objects are } \\
\text { accessible by } \\
\text { district roads }\end{array}$ & $\begin{array}{l}\text { If most tour- } \\
\text { ists objects } \\
\text { are accessi- } \\
\text { ble by pro- } \\
\text { vincial roads }\end{array}$ & $\begin{array}{l}\text { If most tourists } \\
\text { objects are } \\
\text { accessible by } \\
\text { national roads }\end{array}$ \\
\hline
\end{tabular}


JKAP (Jurnal Kebijakan dan Administrasi Publik) Vol.21 (1), May 2017 ---- https://journal.ugm.ac.id/jkap

\begin{tabular}{|c|c|c|c|c|c|c|}
\hline Ease of each & $\begin{array}{l}\text { Ease of reach, } \\
\text { that is the } \\
\text { distance or } \\
\text { duration it } \\
\text { takes from the } \\
\text { center of } \\
\text { tourists gath- } \\
\text { ering point, } \\
\text { main roads } \\
\text { and ease of } \\
\text { reach because } \\
\text { of directions } \\
\text { for visitors to } \\
\text { tourist attrac- } \\
\text { tions }\end{array}$ & $\begin{array}{l}\text { If the objects are not } \\
\text { easy to find because } \\
\text { of lack of directions } \\
\text { and poor roads. }\end{array}$ & $\begin{array}{l}\text { If objects are } \\
\text { difficult to } \\
\text { find, roads are } \\
\text { difficult or } \\
\text { impassable, } \\
\text { but directions } \\
\text { tow objects } \\
\text { are clear }\end{array}$ & $\begin{array}{l}\text { If directions to } \\
\text { objects are } \\
\text { insufficient but } \\
\text { roads are not in } \\
\text { good condition }\end{array}$ & $\begin{array}{l}\text { If directions } \\
\text { to objects are } \\
\text { relatively } \\
\text { good and } \\
\text { roads are } \\
\text { good, but it } \\
\text { takes a long } \\
\text { time for } \\
\text { tourists to } \\
\text { travel from } \\
\text { the gathering } \\
\text { point to } \\
\text { specific } \\
\text { tourists ob- } \\
\text { jects }\end{array}$ & $\begin{array}{l}\text { If directions to } \\
\text { objects are } \\
\text { relatively } \\
\text { good, and } \\
\text { roads are good } \\
\text { and it takes } \\
\text { tourists short } \\
\text { time to travel } \\
\text { from gathering } \\
\text { point to specif- } \\
\text { ic tourist ob- } \\
\text { jects }\end{array}$ \\
\hline
\end{tabular}

\begin{tabular}{|c|c|c|c|c|c|c|}
\hline $\begin{array}{l}\text { Availability of } \\
\text { supporting } \\
\text { infrastructure } \\
\text { and general } \\
\text { facilities }\end{array}$ & $\begin{array}{l}\text { The condition } \\
\text { of infrastruc- } \\
\text { ture and facili- } \\
\text { ties (Quality) } \\
\text { evaluated on } \\
\text { the basis of } \\
\text { the quality of } \\
\text { infrastructure } \\
\text { and facilities } \\
\text { in terms of } \\
\text { whether or } \\
\text { not, functional } \\
\text { and well } \\
\text { maintained. }\end{array}$ & $\begin{array}{l}\text { If infrastructure and } \\
\text { facilities are not func- } \\
\text { tional/damaged or not } \\
\text { at all available }\end{array}$ & $\begin{array}{l}\text { If the condi- } \\
\text { tion of infra- } \\
\text { structure and } \\
\text { facilities is } \\
\text { inadequate } \\
\text { and most of it } \\
\text { is dysfunction- } \\
\text { al }\end{array}$ & $\begin{array}{l}\text { If the condition } \\
\text { of infrastruc- } \\
\text { ture and facili- } \\
\text { ties is good/ } \\
\text { functional, but } \\
\text { not well main- } \\
\text { tained }\end{array}$ & $\begin{array}{l}\text { If the condi- } \\
\text { tion of infra- } \\
\text { structure and } \\
\text { facilities is } \\
\text { just normal }\end{array}$ & $\begin{array}{l}\text { If the condition } \\
\text { of infrastruc- } \\
\text { ture and facili- } \\
\text { ties is good/ } \\
\text { functional and } \\
\text { well main- } \\
\text { tained. }\end{array}$ \\
\hline
\end{tabular}

\begin{tabular}{|c|c|c|c|c|c|c|}
\hline $\begin{array}{l}\text { Completeness } \\
\text { of available } \\
\text { infrastructure } \\
\text { and facilities }\end{array}$ & $\begin{array}{l}\text { Completeness } \\
\text { of available } \\
\text { infrastructure } \\
\text { and facilities } \\
\text { is evaluated } \\
\text { on the basis of } \\
\text { whether or not } \\
\text { there is a } \\
\text { variety of } \\
\text { infrastructure } \\
\text { and facilities } \\
\text { in the tourist } \\
\text { object. }\end{array}$ & $\begin{array}{l}\text { If there is no infra- } \\
\text { structure and facility } \\
\text { available in the area }\end{array}$ & $\begin{array}{l}\text { If there is only } \\
\text { one infrastruc- } \\
\text { ture and facil- } \\
\text { ity available in } \\
\text { the area }\end{array}$ & $\begin{array}{l}\text { If there are two } \\
\text { infrastructure } \\
\text { and facilities in } \\
\text { the area }\end{array}$ & $\begin{array}{l}\text { If there are } \\
\text { three infra- } \\
\text { structure and } \\
\text { facilities in } \\
\text { the area }\end{array}$ & $\begin{array}{l}\text { If there are } \\
\text { four or more } \\
\text { infrastructure } \\
\text { and facilities } \\
\text { in the area }\end{array}$ \\
\hline
\end{tabular}


Yerik Afrianto Singgalen, Pamerdi Giri Wiloso and Gatot Sasongko-Evaluation of the Implementation....

\begin{tabular}{|c|c|c|c|c|c|c|}
\hline Capacity & $\begin{array}{l}\text { Available } \\
\text { capacity is } \\
\text { evaluated } \\
\text { from the } \\
\text { standpoint of } \\
\text { whether or not } \\
\text { available } \\
\text { infrastructure } \\
\text { and facilities } \\
\text { meet the needs } \\
\text { of tourists }\end{array}$ & $\begin{array}{l}\text { If available infrastruc- } \\
\text { ture and facilities do } \\
\text { not meet the need }\end{array}$ & $\begin{array}{l}\text { If needs of } \\
\text { most of the } \\
\text { visitors are not } \\
\text { met. }\end{array}$ & $\begin{array}{l}\text { If the infra- } \\
\text { structure and } \\
\text { facilities meet } \\
\text { needs of some } \\
\text { of the tourists/ } \\
\text { visitors }\end{array}$ & $\begin{array}{l}\text { If the capaci- } \\
\text { ty of infra- } \\
\text { structure and } \\
\text { facilities } \\
\text { meet all the } \\
\text { needs of } \\
\text { tourists and } \\
\text { visitors }\end{array}$ & $\begin{array}{l}\text { If the capacity } \\
\text { of infrastruc- } \\
\text { ture and facili- } \\
\text { ties meet all } \\
\text { the needs of } \\
\text { tourists and } \\
\text { visitors and } \\
\text { there is still } \\
\text { space or room } \\
\text { for further } \\
\text { development }\end{array}$ \\
\hline
\end{tabular}

\begin{tabular}{|c|c|c|c|c|c|c|}
\hline $\begin{array}{l}\text { Other consid- } \\
\text { erations/ } \\
\text { factors }\end{array}$ & $\begin{array}{l}\text { The impact of } \\
\text { tourism of the } \\
\text { environment, } \\
\text { and social and } \\
\text { economic } \\
\text { activities of } \\
\text { society }\end{array}$ & $\begin{array}{l}\text { If most of the impact } \\
\text { is negative }\end{array}$ & $\begin{array}{l}\text { If the nega- } \\
\text { tive impact is } \\
\text { not much }\end{array}$ & $\begin{array}{l}\text { If there is no } \\
\text { impact }\end{array}$ & $\begin{array}{l}\text { If the posi- } \\
\text { tive impact is } \\
\text { small }\end{array}$ & $\begin{array}{l}\text { If there is a lot } \\
\text { of positive } \\
\text { impact }\end{array}$ \\
\hline
\end{tabular}

are 56 DTW in North Halmahera, which implies that $23 \%$ of tourist areas fall into classification A, $14 \%$ of DTW in classification $\mathrm{B}$, and $63 \%$ of DTW in classification C . This means that North Halmahera has a lot of potential DTW which need improvement in various components of tourism supporting activities to make them good tourist destinations.

Table 4 shows classification of DTW based on the ability of each area to deliver pleasant atmosphere to tourists/visitors, both in terms of uniqueness, variety and quality of DTW, marketing reach, number of tourists visiting the area, accessibility, availability of infrastructure and facilities, and the impact on the environment and socioeconomic of the society.

\section{Analysis of the policy implementation process for tourism development in Bobale, Kakara, Meti, and Tagalaya is- lands}

Weights apportioned to each parameter of each tourist object that are based on quality and uniqueness, variety or diversity, environmental condition, scale of marketing, number of tourists/visitors to the object, supporting accessibility, quality of roads, ease of reach, supporting infrastructure and facilities, completeness of infrastructure and facilities capacity and other considerations do not reflect the conditions on the ground for the tourist objects in Bobale, Kakara, Meti and Tagalaya islands.

Table 5 shows the weights apportioned to each tourist development object in Bobale, Kakara, Meti and Tagalaya islands, which do not reflect conditions on the ground. Based on observation of the research team the uniqueness of tourist attractions in Bobale lies in the production of pearl shell handicraft and relics of the Second World War (bunker used by Japanese soldiers). Kakara Island lies in the local cultural attractions, while the uniqueness of tourist objects in Meti Island are relics of the Second World War that takes the form of fighter plane that lies on the sea bed of the sea in the area. The uniqueness of tourist attractions on Tagalaya Island lies in the coral reefs and mangrove forests. Based on findings of this research there is ample evidence that the uniqueness of tourist attractions on Bobale, Kakara, Meti and Tagalaya islands is both of high quality and extremely unique as they are not easy to find in 


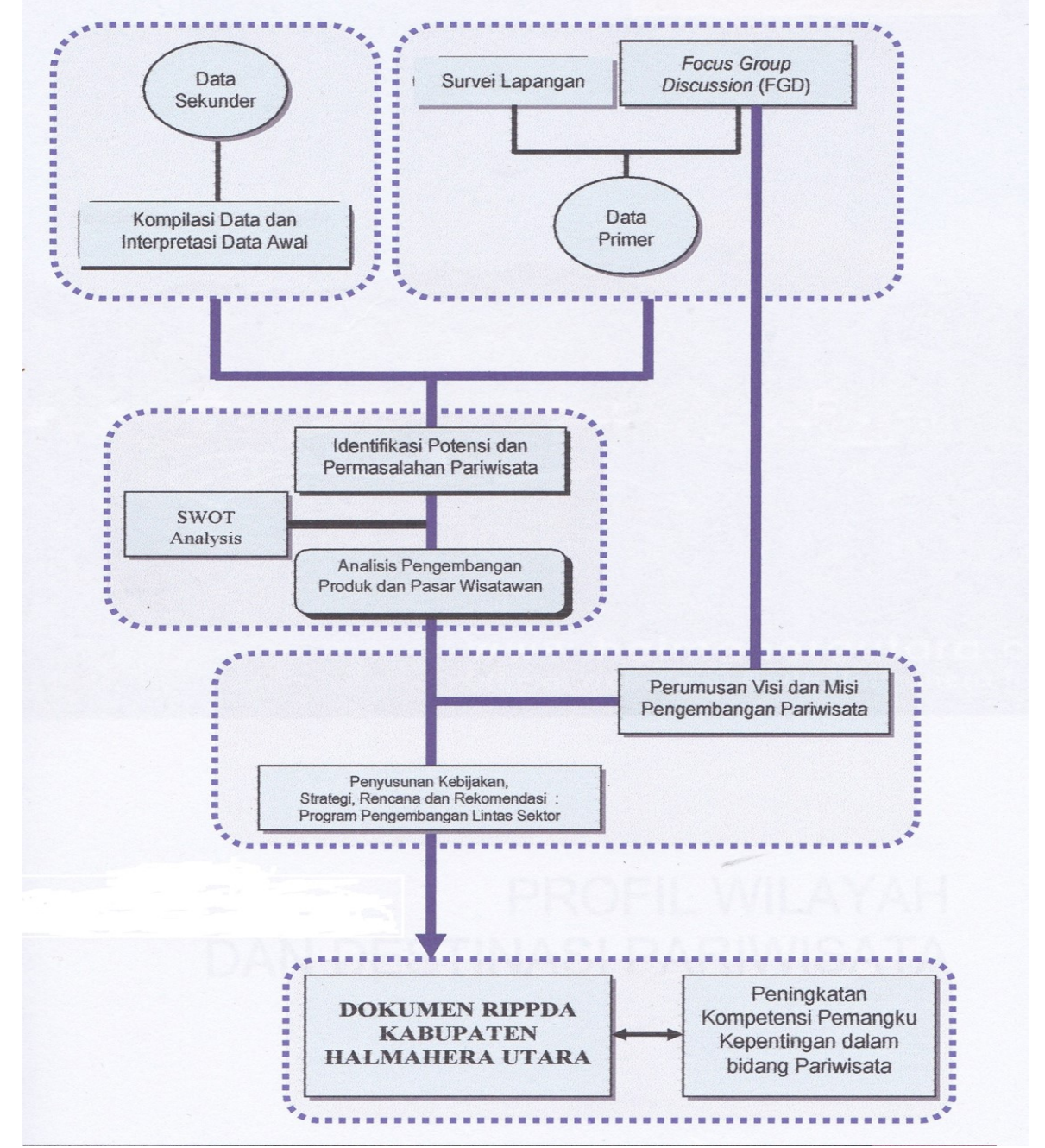

Figure 2. Methods used to formulate RIPPDA in North Halmahera district Source: RIPPARDA HALUT 2011

other locations in the district, but ;lack specific uniqueness. Moreover, with regards to the variety of the tourist attractions, Bobale Island is endowed with aircraft, the beautiful coast, coral reefs and relics of the Second World War. Kakara Island is endowed with three types of tourist attractions, interalia, mangrove forest, coral reefs and local cultural attractions. Tourist attraction on Meti Island include the coast, coral reefs, and relics of the Second World War. Tagalaya Island is endowed with tourist attractions that range from mangrove forests, coast, and coral reefs.

Meanwhile with respect to environmental conditions, Bobale, Kakara, Meti and Tagalaya islands have in place spatial planning and management but still face problems in managing the throng of visitors and re- solving conflicts that arise. Meanwhile the most serious problems that Bobale and Tagalaya islands is the difficulty of tackling vandalism perpetrated on tourist objects as well as supporting infrastructure and facilities. With regards to Kakara Island, the major problem faced is the failure to have an effective way to manage plastic rubbish that litter tourism objects (foods and beverages package visitors bring with them while visiting tourist attractions). Such rubbish is littered along the entire parameter of the coastline. Problems that Meti face relate to absence of proper mechanisms of involving local community in preserving and maintaining tourist object infrastructure and facilities. Meanwhile with regards the scale of tourism marketing, it is worth noting that thanks to internet (social media, websites 
Table 4. Categorization of DTW based on rating

Source: RIPPARDA HALUT 2011

\begin{tabular}{ccc}
\hline Rank & Range of value & Category \\
\hline A & $\mathrm{X}>($ Mean $+($ Standard Deviation/2) $)$ & Competitive \\
B & $($ Mean- $($ Standard Deviation $/ 2))<\mathrm{X}<($ Mean $+($ Standard Deviation/2) $)$ & Outstanding \\
C & $\mathrm{X}<($ Mean- $($ Standard Deviation $/ 2))$ & Potential \\
& & \\
\hline
\end{tabular}

and blogs), attractions on Kakara, Meti and in Bobale, islands have been publicized and known to international tourists. Nonetheless, the number of tourists to the three islands of Bobale, Kakara, Meti and Bobale is still less than 20,000 per year. The small number tourisms to the four islands is largely attributable to lack of sufficient accessibility which is hampered by limited mode of transportation, poor quality of roads that are mainly village roads, ease of reach which is despite having clear directions to tourism attraction still takes long due to the poor condition of roads, despite the availability of four types of tourism supporting infrastructure and facilities that comprise, resting places, bath rooms, drinking water from artesian wells, and so on, most of them are not in good condition. Besides, the needs of visitors and tourists to Bobale, Kakara, Meti and Tagalaya are not met because of the lack of sufficient tourism supporting infrastructure and facilities. Moreover, tourism development of tourist objects on Bobale, Kakara, Meti and Tagalaya islands does not have any impact on the local community. This is because the some members of the local community are involved in tourism activities that generate incomes to their households and the local community as a whole. To that end, if the weights that were apportioned to each components of tourism on the basis of conditions on the ground, the degree of prioritization attached to tourist attractions in the RIPPDA would be very different. The determination of prioritization for tourist objects in accordance with weights apportioned to each component of tourism industry that based on actual conditions on the ground in 2016 on Bobale, Kakara, Meti and Tagalaya islands would be as depicted in Table 6.

To that end, it is easy to determine the difference between the conditions on the ground and the weights assigned in the RIPPDA for North Halmahera district during 2011-2015 fiscal years. It is thus worth noting that assigning weights to tourism parameters that are not in line with conditions on the ground has serious implications for the policy on developing tourist attractions in Bobale, Kakara, Meti and Tagalaya islands.

Based on North Halmahera RIPPDA for 2011-2015, the development of tourist objects on Bobale that is based on the theme "Development of coastal recreation and undersea tourism supplemented by the support of Bobale historic relics". Results of this research show that Bobale Island has a tourist potential in the form of coast and sea tourism which is supplemented by historic relics of the Second World War (PD-II). From an administrative standpoint, Bobale Island is located in North Kao sub district.

Figure 3 shows that Bobale Island is inhabited by the Boeng tribe, most of whom are fisher folks and farmers. The island has artisans who are experts in pearl shell craft that they transform into various accessories that take such forms as rings, bangle, as well as bracelets made from pearl skin and pure pearl On the other hand, the orientation of the development of tourist attractions in RIPPDA is tailored toward creating Bobale island as a destination for coastal recreation and undersea tourism with attractions that range from relaxation, swimming, sea diving, angling using traditional tools, 
Table 5. Weights for the development of tourist objects as apportioned in RIPPDA 2011-2015 Source: RIPPDA HALUT 2011

\begin{tabular}{|c|c|c|c|c|}
\hline Parameter for tourist object development & Bobale Island & $\begin{array}{c}\text { Kakara } \\
\text { Island }\end{array}$ & $\begin{array}{l}\text { Meti Is- } \\
\text { land }\end{array}$ & Tagalaya Island \\
\hline Quality and uniqueness of the tourist object & 4 & 3 & 2 & 4 \\
\hline Variety inherent in the tourist attractions & 3 & 3 & 2 & 4 \\
\hline Environmental condition & 3 & 3 & 2 & 4 \\
\hline Scale of marketing & 2 & 3 & 2 & 4 \\
\hline $\begin{array}{l}\text { Number of tourists paying visits to the tour- } \\
\text { ist object }\end{array}$ & 3 & 3 & 2 & 3 \\
\hline Accessibility and reach of the tourist object & 2 & 3 & 3 & 4 \\
\hline Quality of roads & 2 & 3 & 3 & 3 \\
\hline Ease of reach & 3 & 3 & 3 & 4 \\
\hline Supporting infrastructure and facilities & 3 & 4 & 2 & 3 \\
\hline Completeness of infrastructure and facilities & 2 & 3 & 2 & 3 \\
\hline Capacity & 3 & 4 & 3 & 3 \\
\hline Other considerations/factors & 3 & 3 & 3 & 4 \\
\hline Total & 2.75 & 3.07 & 33.67 & 3.65 \\
\hline Scale & 39.66 & 56.03 & 100 & 86.21 \\
\hline Category & A & B & $\mathrm{C}$ & A \\
\hline
\end{tabular}

fishing, , jet sky, banana boat, under sea water photography, sun bathing, canoeing, spending a night on the island, culinary activities, exploring the island, and history. Meanwhile, with regards the development of tourism infrastructure and facilities, the list includes construction of a resort, boarding house, homestay, villas on areas in the vicinity of the coast; construction of easterly that serves local foods, with a menu that has various themes of sea food; developing a diving center with sufficient facilities that support surface and undersea diving activities; developing fishing rods for sea and boat fishing explorations on the island; providing clear water facilities and electricity; and providing certified tourist guide service. In the mean, as regards the development of accessibility, activities that envisioned include improving the availability of Tobelo-daru sea transport, developing ship dock in
Bobale, providing seas crossing services to Bobale, enhancing the quality of roads leading to and from tourist attractions on Bobale Island. That said, not all the above development plans have been implemented by the time the research team paid visits to various tourist objects on the island.

Figure 4 shows the state of tourism infrastructure and facilities which was constructed not long ago has already been reduced to a state of disrepair by the local population. This is attributable to the fact that the district offices in charge of tourism and culture and others relevant to the exercise, did not conduct socialization efforts of such programs to society, nor was the local population trained on the rationale for the development of such facilities. This shops that communication between Bobale village community and officials of the district tourism and culture office was harnessed and 
Table 6. Evaluation of Tourist development objects on the basis of data obtained from the field/ ground 2016

\begin{tabular}{lcccc}
\hline \multicolumn{1}{c}{ Tourist object development parameter } & Bobale island & Kakara island & Meti island & Tagalaya island \\
\hline Quality and Uniqueness of tourist objects & 2 & 2 & 2 & 2 \\
Variety of tourist attractions & 3 & 3 & 2 & 2 \\
Environmental condition & 3 & 3 & 3 & 3 \\
Marketing scale & 5 & 5 & 5 & 5 \\
The number of tourists visiting the attrac- & 1 & 1 & 1 & 1 \\
tions & 2 & 2 & 2 & 2 \\
Supporting accessibility and reach & 1 & 1 & 1 & 1 \\
Quality of roads & 4 & 4 & 4 & 4 \\
Ease of reach & 1 & 1 & 1 & 1 \\
Supporting infrastructure and facilities & 5 & 5 & 5 & 5 \\
Completeness of infrastructure and facili- & & & 2 & 2 \\
ties & 2 & 2 & 3 & 3 \\
Capacity & 3 & 3 & & \\
Other considerations & & & \\
\hline
\end{tabular}

managed well. The implication is that little communication between the district government and local society affected their participation in the development of tourism in the area. Based on the results of an Interview with an informant in Bobale village, the research team got to know that the local government conducts little control and coordination with the local community which hampers them from understanding the benefits of development and function of infrastructure and facilities that were developed along Bobale coast. Moreover, the local community assumes a passive attitude toward tourism development on Bobale Island of the limited knowledge members have about tourism. To that end, it is evident that communication among stakeholders is the most important problem that hampers tourism development on Bobale Island. According to Firdaus (2016), the central government can coordinate the implementation of tourism programs with the private sector within in a collaborative arrangement that is tailored toward achieving the goals of developing tourism on Bobale Island.

Meanwhile, as regards Kakara Island, the theme of development of tourist objects it adopted in RIPPDA, North Halmahera for 2011-2015 period, is similar to that used by Bobale Island. The only difference in tourist object development programs lies in the development accessibility to tourist attractions. From the administrative viewpoint, Kakara Island is part of Tobelo sub district.

Figure 5 shows that Kakara island map has a residential area that forms the Kakara village. There is a long distance between tourist objects and Kakara village settlement, approximately a kilometer by walking on foot. Nonetheless, the local population prefer to use sea transportation in the form of traditional boats (ketinting) from Tanjung Kakara tourist attraction to Kakara village. The journey from the Kakara village to the tourist attraction takes about 5-10 minutes. The problem which the process of developing tourism in Kakara is trash and rubbish that is littered everywhere along the beach / coastline.

Figure 6 shows that trash and rubbish that litters along the entire coastline and beach is the most serious problem that Tourism management in Tanjung Kakara tourism faces What is also worth noting is that unlike Bobale island, Kakara island has well maintained infrastructure and facilities. Besides, Kakara has good communication, which fosters coordination, between tourism and culture office and tourist object management. That said, the problem that the tourist object management on Kakara island faces is scarcity of human resources to serve as tourist object management who lack ample knowledge on tourism management, tourism product development and management, developing products and marketing of tourism destinations which has led to the emergence of a new problem, namely plastic trash the litter tourist objects. Based on results of the interview with informants, poor management of tourist objects on $\mathrm{Ka}$ - 


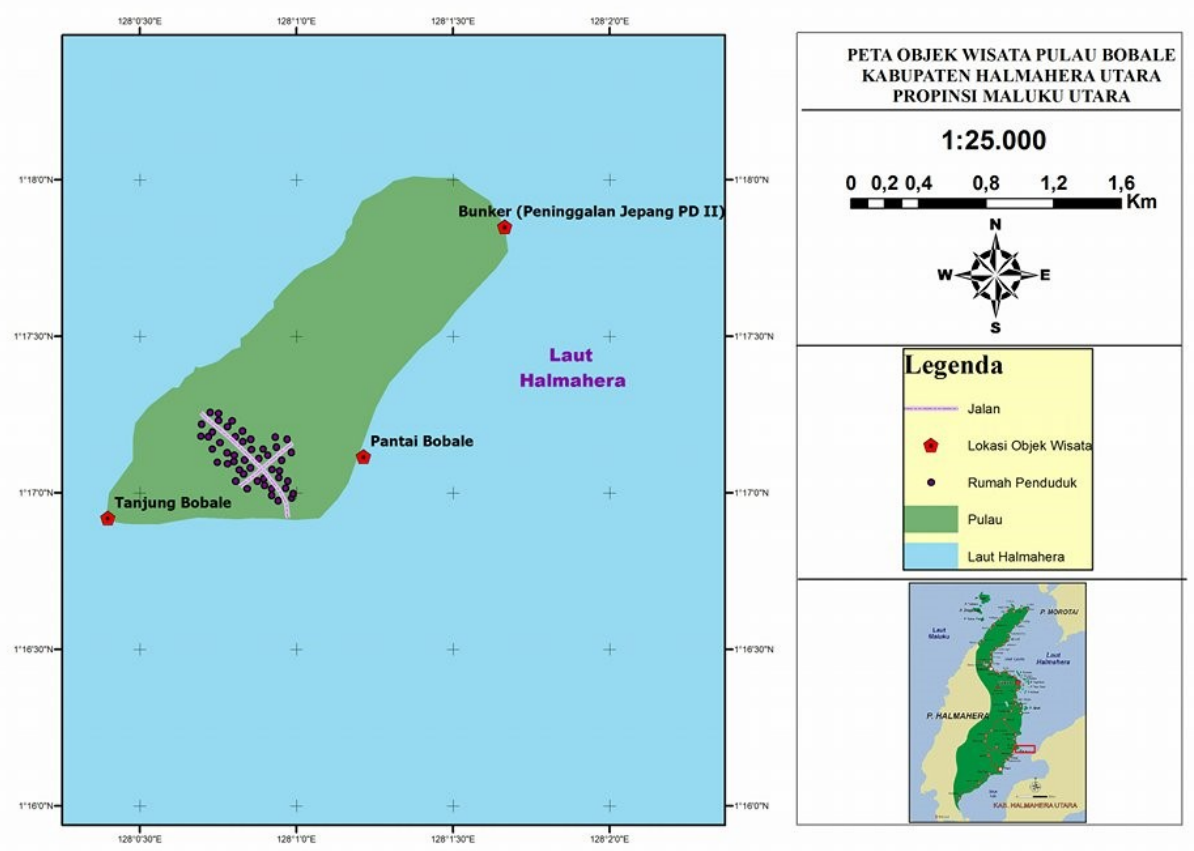

Figure 3. Map of Tourist Objects on Bobale Island

Source: Digital map 2016

kara Island has undermined supervision and control of tourists who carry foods and beverages during their visits. Consequently, tourists end up throwing plastic trash along tourist objects. Besides, another problem is the lack of funds to finance training of the local community in order to change their habits of throwing trash and help to clean the shoreline. In other words, scarcity of resources is the most serious problems that Kakara tourism development efforts face. This includes human resources (HR) and financial resources. This is indeed what Faramalala (2016) noted when he contended that HR which has a good understanding of tourism management, and policy, and have ample knowledge on how to involve the members of society in the development of tourism activities, will help in enhancing people's understanding and awareness of the importance of tourism hence readiness to contribute to its development.

With respect to Meti Island, the theme on developing tourist objects is similar to that adopted by Bobale and Kakara islands. From an administrative standpoint, Meti Island is located in East Tobelo sub distric.

Figure 7 shows that Meti Island is inhabited by the same who are found on
Bobale and Kakara islands. The same applies to tourist attractions the island has. Meti Island is endowed with coast and sea tourism which is supplemented by relics of the Second World War in the form of a fighter aircraft which lies in the sea waterss and can be viewed by tourists by diving. The location of the coastal tourism is somewhat detached from the settlement and takes about 10 minuets on foot for one to walk the distance between Meti village and the tourist attraction. Alternatively, one can use traditional boat to travel the same distance. The damage to supporting infrastructure and facilities that has been inflicted on tourist objects is the most serious problem that tourism development in the area faces. This has been largely due to poor communication between the tourism and culture office and tourist object management.

Figure 8 which is a report of the research results obtained on the ground on infrastructure and facilities in tourist objects on Meti Island attests to the poor state of maintenance and decay they are in. Based on the results of an interview with informants, it was disclosed that there is very little coordination between tourist object management and the district tourism and culture office. 


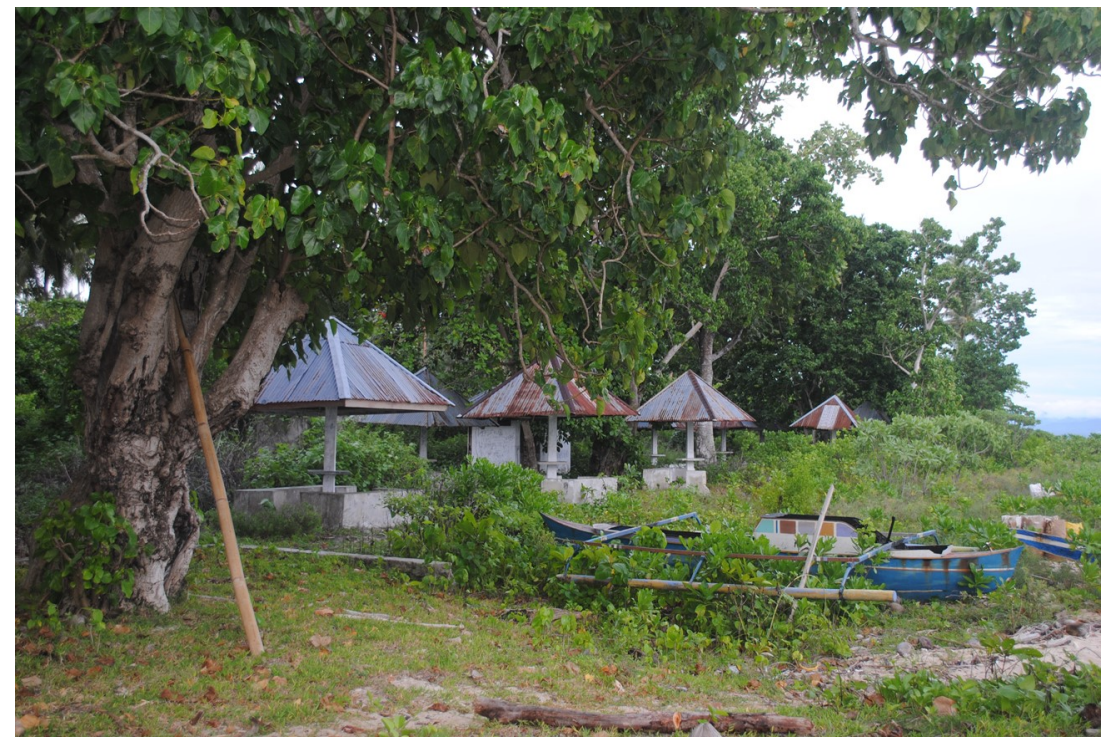

Figure 4. The scale of damage to tourism infrastructure and facilities Source: Data from observations (2016)

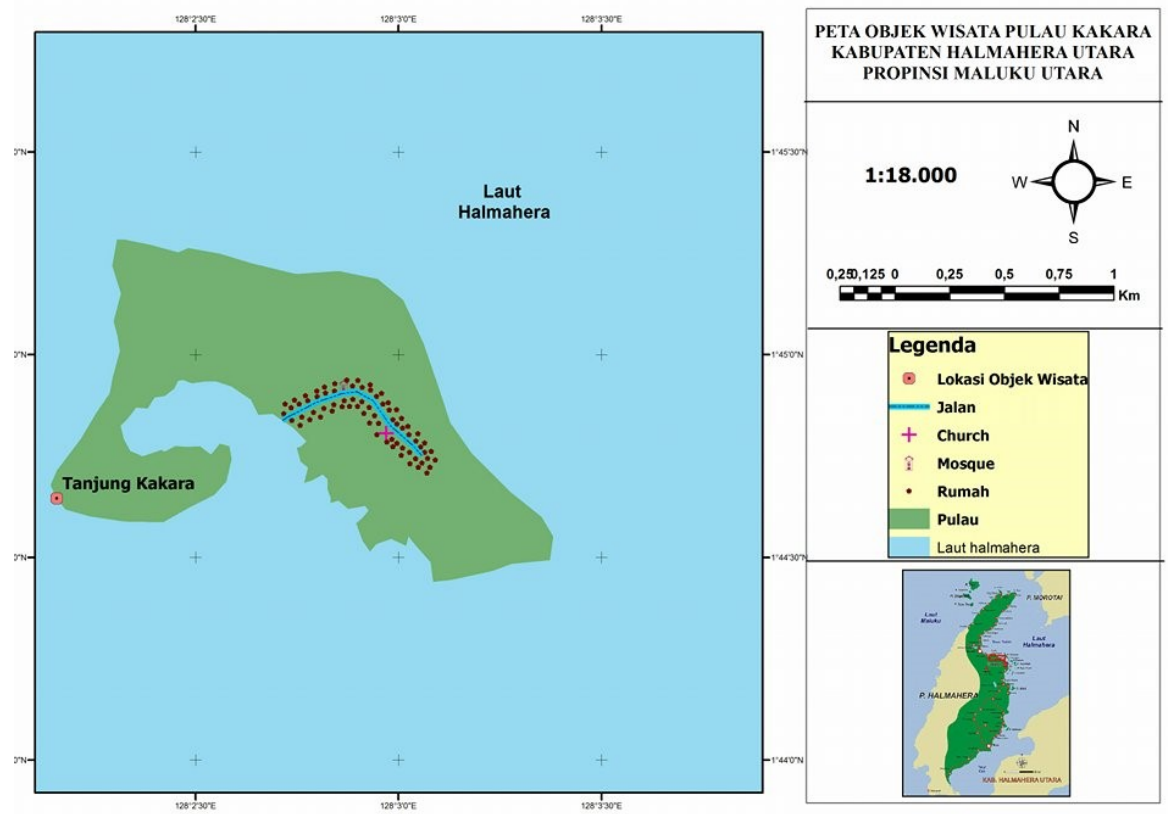

Figure 5. Map of Tourist Objects on Bobale Island Source: Digital map 2016

This is particularly so on issues that relate to socialization and training of tourism development that require intensive collaboration from relevant stakeholders. Besides, the failure to reach amicable outcome in conflicts between owners of land that is in the vicinity of tourist objects and the village administration on payment for land that has been designated for future tourism object development has undermined efforts to implement developments programs that are aimed at improving infrastructure and facilities in tourist attractions. Moreover, other problems that have hampered tourism development on the island relate to the attitude and disposition of implementers of the land acquisition program for tourism object development. To that end, based on the observation and factors on the ground, it can be argued that bureaucracy of the village administration on Meti Island in general and their attitude and disposition in particular, is 


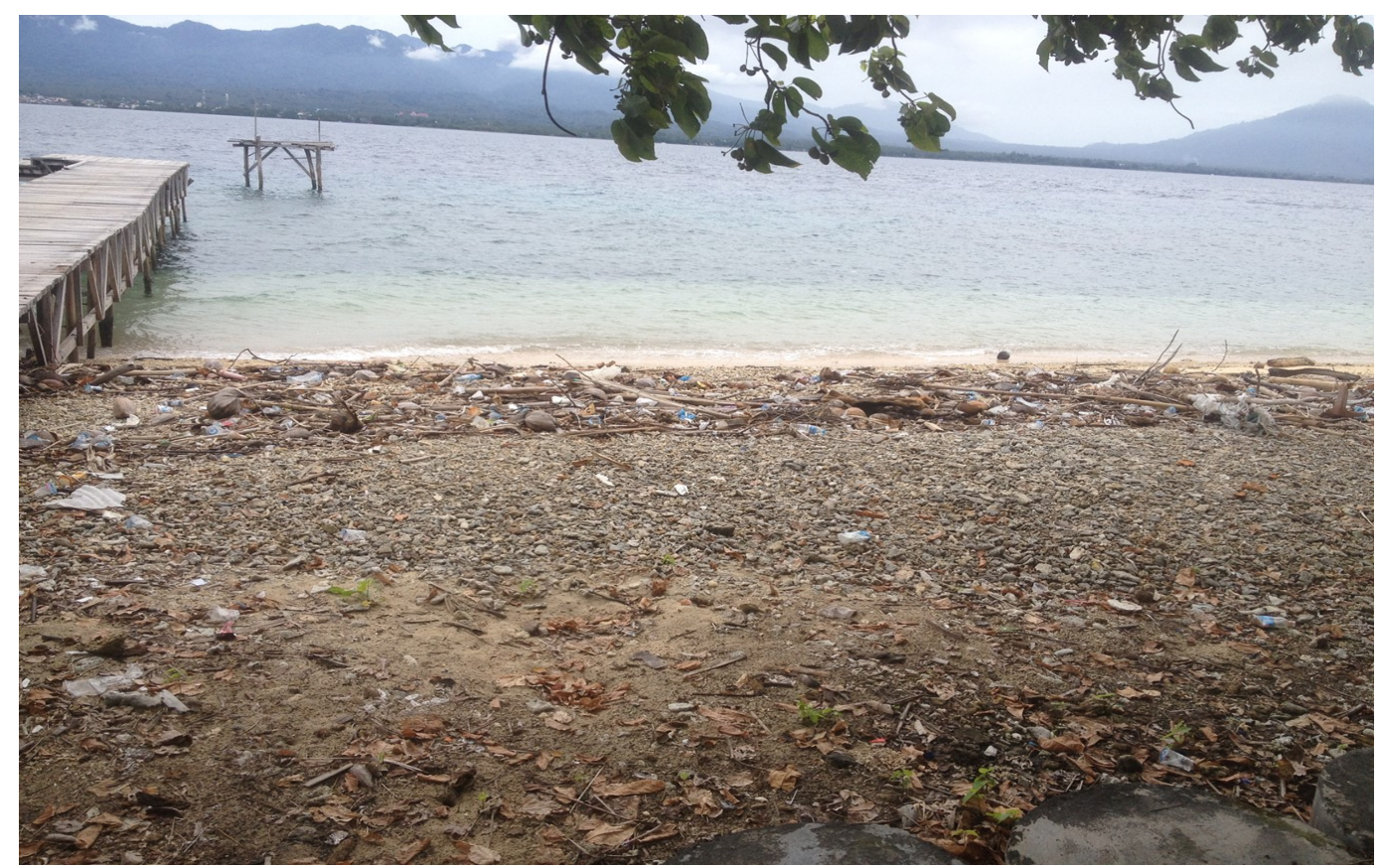

Figure 6. Plastic Trash and rubbish that litters the entire Kakara coastline Source: Data from observations (2016)

the most important obstacle that has undermined the development of tourism on the island.

Meanwhile, tourism on Tagalaya, which developed the theme of tourism development in RIPPDA North Halmahera for 2011-2015 that goes as "developing coastal/ beach recreation and undersea potential underpinned by cultural village and the exotic Uniqueness of mangrove forest". From an administrative standpoint, Tagalaya Island is located in Tobelo sub district.

Figure 9 shows that the map of Tagalaya tourist attractions differs from those of Kakara, Bobale and Meti Island. This is largely because of the fact that one cannot reach the tourist attraction from the village settlement by foot, rather must use a traditional boat (ketinting). Tourist attract on Tagalaya island lies under the sea within the crevices of mangrove forests that dot the coastline. In addition, the natural beauty under the sea that takes the form of coral reefs has special uniqueness of its own. Nonetheless, tourism development on Tagalaya Island faces the same problem as that on Bobale and Meti Island, which is limited coordination between district tourism and culture office and tourist object management, which has led to poor management of tourist objects.

Thus, in general based on research findings, we can succinctly note that the key factors that influence the performance of the implementation of tourism policy on Bobale, Kakara, Meti, and Tagalaya islands are resources, attitude and disposition of implementers of programs, communication and the bureaucracy system.

Table 7 shows that communication is the most dominant factor that influences tourism development policy on Bobale Island. The tourism development implementation policy on Bobale and Tagalaya islands is not as effective as it should because of obstacles in communication, in which this case relates to communication among stakeholders (tourism and culture office, village government, and society). Mouw (2012) shows that communication or coordination play a key role in the implementation of tourism policy. Subsequently, resources is the most dominant factor that influences the performance of tourism development policy on Kakara Island. Resource constraints in forms of human resources and financial resources that Kakara Island faces hamper the successful implementation of tourism development policy on Bobale Island. This finding corroborates the research finding by Ju- 


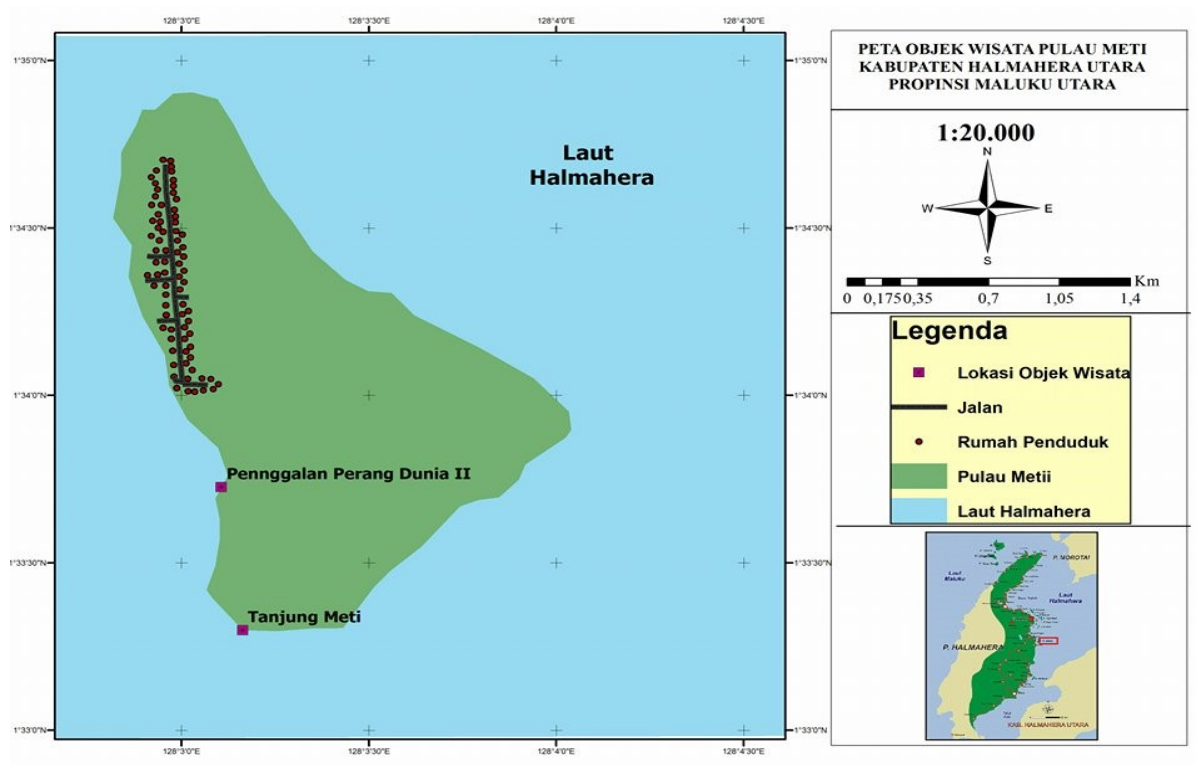

Figure 7. The Map of Tourist Objects on Meti Island Source: Digital map 2016

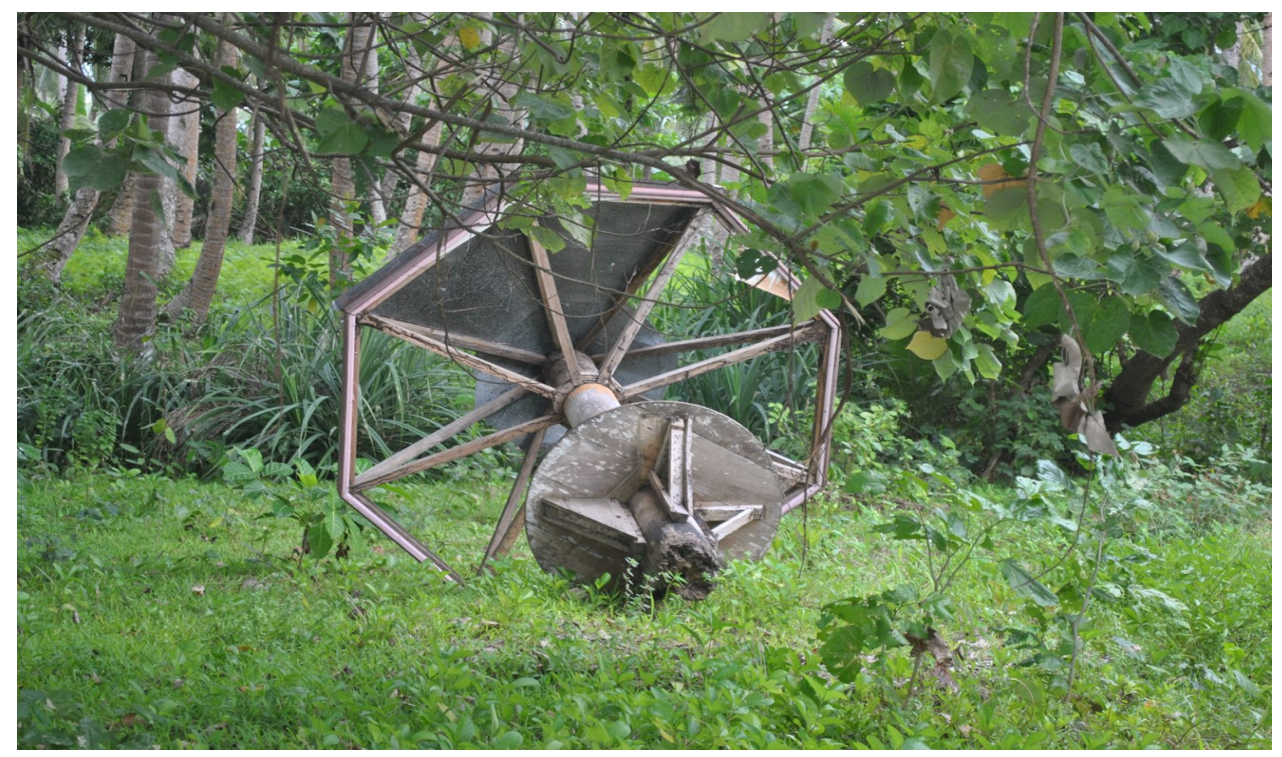

Figure 8. The scale of damage on supporting infrastructure and facilities Source: Data from observations (2016)

pir (2013) that tourism development implementation policy is sub optimum whenever there is scarcity of human resources both in quality and quantity. On the other hand, bureaucratic system, is the most dominant factor that influences tourism development policy on Meti Island. The implementation of tourism development policy cannot be realized if the bureaucracy that plays the most crucial role in the process is plagued by problems that range from difficulty of land acquisition, complexity of bureaucratic mechanisms, and disposition of implementers of the land acquisition program that is not supportive of the development process. Feriani (2009) and (Muzha, 2013) found that the attitude and disposition of policy implementers and system of bureaucracy influence the implementation of tourism development policy. In relation to the system of bureaucracy, (Pradana, 2013) emphasized that bureaucracy must profess and practice transparency at all levels of the bureaucratic hierarchy, which is a prerequisite for a 


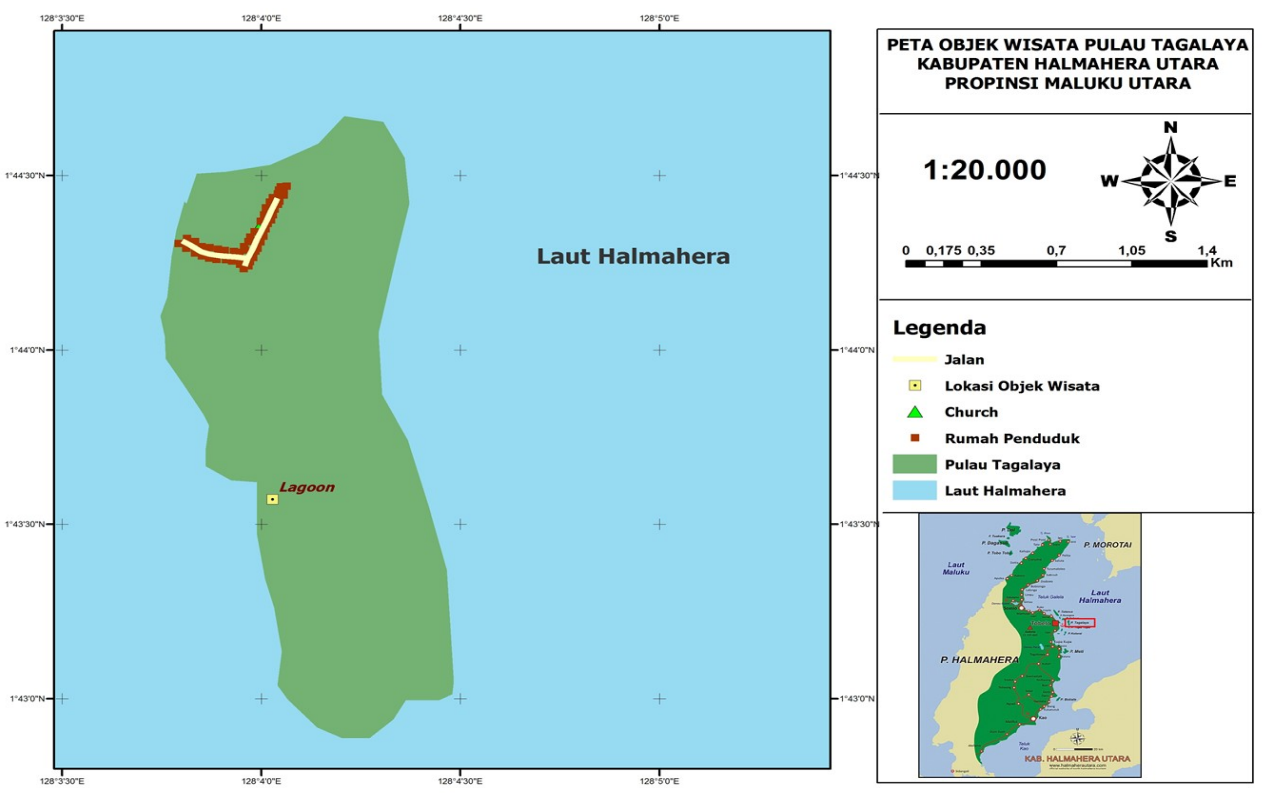

Figure 9. Map of Tagalaya tourist objects

Source: Digital map 2016

smooth and accountable implementation of the policy. Thus, if transparency is adopted and implemented in the tourism development policy on Meti Island, there is no doubt that the un-supportive attitude and disposition of the bureaucracy which has so far hampered program execution would be reduced if not eradicated.

This research has found that public support through its involvement in the policy process influences the implementation of tourism development policy on Bobale, Kakara, and Meti and Tagalaya islands. Meanwhile, public support requires the existence of a public sector that is accountable to the public through transparent program plans, source of public revenues and requisition of public expenditures in implementing programs, and offer the public the opportunity to participate in the planning process as decision makers. Such finding is evident in a research by (Wicaksono, 2015) who shows that transparency, accountability, control, and responsiveness have not been fully adopted and applied through providing detailed explanation of the use of public funds in managing public programs, projects, and other routine activities. Whenever policy implementers uphold accountability to the fullest extent, that creates an opportunity to the public to participate in the decision making process. Besides, (Setyati \& Utomo, 2015) contend that economic factors, and personal organizational interests also create conditions that lead to an imbalance between the formulated and implemented policy. This shows that accountability obstacles in the public sector also influence individual interests that are manifested in economic factors.

With regards to public participation, it is well established that public support in Bobale, Kakara, Meti and Tagalaya Island is still very limited and minimal. Limited public participation undermines collaboration and cooperation with stakeholders in the development of tourism. To that end, it can be stated succinctly that the implementation of tourism policy has not performed in accordance with expectations because not all the initial targets have been achieved. This finding therefore underscores the need for the government and private sector to galvanize the tourism development process, in such a manner as (Fathin, 2016) recommends with respect to the role of the private sector in the initial phases of the development of Yogyakarta region as well as findings by (Sidik, 2015) that the communication prowess of the tourism and culture office of the planning, development and direction and control of tourism development are essential ingredients of enhancing public participation in the development of tourism (RIPPDA and RIPPOW) along with local population, which in turn paves way for achieving sus- 
Table 7. Key Factors that influence the development of tourist objects

\begin{tabular}{|c|c|c|c|c|}
\hline $\begin{array}{l}\text { Factors that influence policy } \\
\text { implementation process }\end{array}$ & Bobale Island & $\begin{array}{c}\text { Kakara } \\
\text { Island }\end{array}$ & Meti Island & $\begin{array}{c}\text { Tagalaya } \\
\text { Island }\end{array}$ \\
\hline Resources & & $\mathrm{X}$ & & \\
\hline Disposition of implementers & & & $\mathrm{x}$ & \\
\hline Communication & $\mathrm{x}$ & & & $\mathrm{x}$ \\
\hline Bureaucracy & & & $\mathrm{x}$ & \\
\hline
\end{tabular}

tainable tourism (Wray, 2011).

\section{CONCLUSION}

Results in this research have highlighted the key factors that influence the implementation of the policy of developing tourist objects on Bobale, Meti, Tagalaya and Kakara islands interalia resources, communication, disposition of program implementers and bureaucratic system. Besides, the importance of public participation in supporting tourism development policy is another factor that should be on the list of priorities.

To ensure that the implementation of tourism development policy on Bobale, Meti, Tagalaya, and Kakara islands runs smoothly, the research team makes the following recommendations:

a. The need for socialization of Sapta Pesona and tourism awareness. By ratcheting up socialization, the tourism and culture office, North Halmahera district can enhance its coordination with the public who live and work in the vicinity of tourist objects while at the same increasing their understanding of the importance and benefits of tourism.

b. Training. The tourism and culture office can empower the local population by proving training on tourism related issues such as ethics of tourist guidance services, training on the formulation of Master plan for the development of tourist objects (RIPOW), information technology based training in tourist object promotion, training in packaging and developing local tourism products and training on the formulation of tourist objects development program implementation reports.

c. Enhance the effectiveness of the tourism and culture office, North Halmahera. This should can be through enhancing communication, resources, attitude and disposition of program and project implementers and bureaucracy system. All that is possible when and if, the tourism and culture office, North must lends support for tourism development programs in RIPPDA HALUT.

\section{REFERENCES}

Agistiani, N. (2014). Pengukuran Kinerja Implementasi Kebijakan Penanggulangan Kemiskinan Studi Kasus : Implementasi Program Nasional Pemberdayaan Masyarakat Mandiri Pariwisata di Desa Wisata Brayut. Tesis Magister Administrasi Publik Universitas Gadjah Mada.

Basri. 2002. Kajian Empiris Implementasi Rencana Induk Pengembangan Pariwisata Daerah (RIPPDA) Kalimantan Barat. Tesis. Magister Perencanaan Kota dan Daerah Universitas Gadjah Mada.

Brida, J. G., \& Risso, W. A. (2010). Tourism as a determinant of long-run economic growth. Journal of Policy Research in Tourism, Leisure and Events, 2(1), 14-28. https:// doi.org/10.1080/19407960903542276 
Curry, N., \& Brown, K. (2010). Differentiating outdoor recreation: evidence drawn from national surveys in Scotland. Journal of Policy Research in Tourism, Leisure \& Events, 2(1), 29. https:// doi.org/10.1080/19407960903542300

Dewi, G. (2005). Analisis Efektivitas Implementasi Kebijakan Pengembangan Pariwisata di Kota Palembang. Tesis. Magister Administrasi Publik Universitas Gadjah Mada.

Doherty, A. (2009). The volunteer legacy of a major sport event. Journal of Policy Research in Tourism, Leisure and Events, 1(3), 185-207. https:// doi.org/10.1080/19407960903204356

Dredge, D., \& Whitford, M. (2011). Event tourism governance and the public sphere, (January 2015), 37-41. https:// doi.org/10.1080/09669582.2011.57307 4

Fathin, C. A. (2016). Analysis of Three Actors: Roles of Government, Private Sector, and University toward Startup Growth in Yogyakarta, 20(1).

Fianda, W. (2008) Implementasi Kebijakan Pengembangan Pariwisata di Kota Bukittinggi. Tesis. Magister Administrasi Publik Universitas Gadjah Mada.

Firdaus. (2016). Sound Governance in Case of Mamminasata Metropolitan Development Area in South Sulawesi Province. JKAP (Jurnal Kebijakan dan Administrasi Publik), 20(1), 1-22.

Getz, D., \& Page, S. J. (2005). Successful event management: a practical handbook. Tourism Management, 26(May), 628-630. https://doi.org/10.1016/ j.tourman.2004.02.008

Habbibuw, Y. (1997). Implementasi Kebijakan Program Pengembangan Pariwisata Daerah (Studi Kasus RIPP di Kabupaten Mojokerto). Tesis. Magister Administrasi Publik Universitas Gadjah Mada.

Hall, C. M. (2009). Innovation and tourism policy in Australia and New Zealand: never the twain shall meet? Journal of Policy Research in Tourism, Leisure and Events, 1(1), 2-18. https:// doi.org/10.1080/19407960802703466
Hall, C. M. (2011). Journal of Sustainable Tourism Sustaining urban placemaking, (January 2015), 37-41. https:// doi.org/10.1080/09669582.2010.51658 5

Haydock, W. (2014). The "civilising" effect of a "balanced" night-time economy for "better people": Class and the cosmopolitan limit in the consumption and regulation of alcohol in Bournemouth. Journal of Policy Research in Tourism, Leisure and Events, 6(2), 172-185. https:// doi.org/10.1080/19407963.2014.90098 9

Hutapea, T. (2001). Implementasi Kebijakan Penyelenggaraan Pariwisata : Studi Kasus Kawasan Wisata Teluk Yotefa Kota Jayapura. Tesis. Magister Administrasi Publik Universitas Gadjah Mada.

Jupir, M. (2013). Implementasi Kebijakan Pariwisata Berbasis Kearifan Lokal (Studi di Kabupaten Manggarai Barat). Journal of Indonesian Tourism and Development Studies, Vol 1(1): 28-37.

Kadir, A. (1996). Analisis Implementasi Kebijakan Pengembangan Sektor Pariwisata Daerah (Studi Kasus Provinsi Daerah Istimewa Aceh). Tesis. Magister Administrasi Publik Universitas Gadjah Mada.

Mouw, E. (2012). Implementasi Kebijakan Pengembangan Pariwisata Bahari di Kabupaten Halmahera Barat. Tesis. Magister Administrasi Publik Universitas Gadjah Mada.

Muzha, V. K. (2013). Pengembangan agrowisata dengan pendekatan Community Based Tourism (Studi pada Dinas Pariwisata Kota Batu dan Kusuma Agrowisata Batu). Jurnal Administrasi Publik, 1(3), 135-141. Retrieved from http://

administrasipub-

lik.studentjournal.ub.ac.id/index.php/ jap/article/view/81

Nunkoo, R., \& Ramkissoon, H. (2010). Community perceptions of tourism in small island states: a conceptual framework. Journal of Policy Research in Tourism, Leisure and Events, 2(January 2014), 51-65. https:// 
Yerik Afrianto Singgalen, Pamerdi Giri Wiloso and Gatot Sasongko-Evaluation of the Implementation....

doi.org/10.1080/19407960903542318

O'Sullivana, D., Pickernella, D., \& Senyardb, J. (2009). Public sector evaluation of festivals and special events. Journal of Policy Research in Tourism, Leisure and Events, 1(1), 19-36. https:// doi.org/10.1080/19407960802703482

Pakpahan, E. (1999). Implementasi Kebijakan Pengembangan Kelembagaan di Dinas Pariwisata Provinsi Daerah Istimewa Yogyakarta. Tesis. Magister Administrasi Publik Universitas Gadjah Mada.

Pradana, I. P. Y. B. (2013). Transparansi Birokrasi dalam Pengelolaan APBD di Kota Kupang, (September).

Preuss, H. (2009). Opportunity costs and efficiency of investments in mega sport events. Journal of Policy Research in Tourism, Leisure and Events, 1(2), 131 -140. $\quad$ https:// doi.org/10.1080/19407960902992183

Rettob, I. (2008). Implementasi Rencana induk Pengembangan Pariwisata Daerah (RIPPDA) Provinsi Papua (Irian Jaya). Tesis. Magister Administrasi Publik Universitas Gadjah Mada.

Roberts, K. (2010). Contemporary policy debates: Can employment policies improve a society's leisure? Journal of Policy Research in Tourism, Leisure and Events, 2(1), 82-87. https:// doi.org/10.1080/19407960903542391

Robertson, M., Rogers, P., \& Leask, A. (2009). Progressing socio-cultural impact evaluation for festivals. Journal of Policy Research in Tourism, Leisure and Events, 1(2), 156-169. https:// doi.org/10.1080/19407960902992233

Saayman, M., Van der Merwe, P., Saayman, A., \& Mouton, M. E. (2009). The socio -economic impact of an urban park: the case of Wilderness National Park. Journal of Policy Research in Tourism, Leisure and Events, 1(3), 247-264. https:// doi.org/10.1080/19407960903204380

Setyati, R., \& Utomo, W. (2015). Implementasi Kebijakan Penataan Ruang Terbuka Hijau Kawasan Perumahan Kota Banjarbaru. Jurnal Kebijakan Dan Administrasi Publik, 19(1), 59-70.
Sidik, F. (2015). Menggali Potensi Lokal Mewujudkan Kemandirian Desa. Jurnal Kebijakan \& Administrasi Publik, 19 (2), 115-131.

Theodoraki, E. (2009). Organisational communication on the impacts of the Athens 2004 Olympic Games. Journal of Policy Research in Tourism, Leisure and Events, 1(2), 141-155. https:// doi.org/10.1080/19407960902992191

Veriani, R. (2009). Implementasi Kebijakan Pengembangan Kawasan Wisata Kabupaten Kebumen. Tesis. Magister Administrasi Publik Universitas Gadjah Mada.

Wesley, A., \& Pforr, C. (2010). The governance of coastal tourism : unravelling the layers of complexity at Smiths Beach, Western Australia, (January 2015), 3741.

https:// doi.org/10.1080/09669581003721273

Wicaksono, K. W. (2015). Akuntabilitas Organisasi Sektor Publik. Jurnal Kebijakan Dan Administrasi Publik, 19 (1), 3-12.

Wray, M. (2011). Adopting and implementing a transactive approach to sustainable tourism planning : translating theory into practice, (January 2015), 37-41. https:// doi.org/10.1080/09669582.2011.56692 8

Yaghmour, S., \& Scott, N. (2009). Interorganizational collaboration characteristics and outcomes: a case study of the Jeddah Festival. Journal of Policy Research in Tourism, Leisure and Events, 1(2), 115-130. https:// doi.org/10.1080/19407960902992175

Yang, H., \& Chen, K. (2009). A general equilibrium analysis of the economic impact of a tourism crisis: a case study of the SARS epidemic in Taiwan. Journal of Policy Research in Tourism, Leisure and Events, 1(1), 37-60. https:// doi.org/10.1080/19407960902738313 